\title{
Upper limb function and functional independence in patients with shoulder pain after stroke
}

\author{
Função do membro superior e independência funcional em pacientes com ombro doloroso \\ após AVC
}

Renato Nickel', Marcos Lange², Diane Priscila Stoffel', Elaine Janeczko Navarro³, Viviane F Zetola²

\begin{abstract}
Objective: To examine the frequency of shoulder pain following stroke. Methods: Stroke patient function was evaluated using the Functional Independence Measure (FIM) and Scale for Upper Limb Function in Stroke (SULFS). Function scores were examined and compared between the shoulder pain group (SPG) and the no shoulder pain group (No-SPG). Results: A total of 58 patients, 22 women (37.9\%), were included in this study. The mean patient age was $49.2 \pm 10.8$ years and study evaluations were done $3.52 \pm 2.26$ months after stroke. A total of 16 patients (27.6\%) were in the SPG and 42 patients (72.4\%) were in the No-SPG. The SPG scored significantly lower on the FIM (SPG: $91.06 \pm 14.65$ vs. No-SPG: $114.62 \pm 2.27 ; p<0.01$ ) and SULFS (SPG median: 2 [range: 1-4], No-SPG median: 5 [range: 1-5]; p < 0.01) than the No-SPG. Conclusion: Shoulder pain commonly occurs after stroke and is related to the affected upper limb function and functional independence in stroke patients.
\end{abstract}

Keywords: stroke; shoulder pain; rehabilitation; activities of daily living.

\section{RESUMO}

Objetivo: Identificar a frequência de ombro doloroso após acidente vascular cerebral (AVC). Métodos: Avaliação funcional de pacientes pós-AVC foi realizada pela Medida de Independência Funcional (MIF) e pela Escala de Função de Membro Superior pós-AVC (EFMSA). As pontuações foram comparadas entre pacientes com ombro doloroso (PcOD) e pacientes sem ombro doloroso (PsOD). Resultados: 58 pacientes foram incluídos no estudo, sendo 22 (37,9\%) mulheres. A idade média dos pacientes foi 49,2 $\pm 10,8$ anos e a avaliação foi realizada 3,52 $\pm 2,26$ após o AVC. Dezesseis (27,6\%) pacientes foram incluídos no grupo PcOD e 42 (72,4\%) no grupo PsOD. A MIF foi menor no grupo PCOD $(91,06 \pm 14,65)$ quando comparados ao grupo PsOD $(114,62 \pm 2,27)$, p < 0.01. A EFMSA também foi menor no grupo PcOD (mediana: 2 [intervalo: 1-4] em comparação ao grupo PsOD (mediana: 5 [intervalo: 1-5], p < 0.01 . Conclusão: Ombro doloroso é comum após AVC e afeta de forma significativa a função do membro superior e a independência funcional.

Palavras-chave: acidente vascular cerebral; dor de ombro; reabilitação; atividades cotidianas.

Shoulder pain often occurs in adults with hemiplegia and is known to contribute to functional disability ${ }^{1}$. Its etiology remains uncertain, but it is multifactorial and causes changes in structure and function, including abnormal muscle tone, subluxation, and limited external rotation ${ }^{2,3,4}$. In addition, these patients often need transfer assistance to gain mobility, which can include the use of pulleys (e.g., the shoulder wheel). These techniques may be inappropriately provided, which may make hemiplegic patients with shoulder pain vulnerable to lesions ${ }^{3}$.

Prevention and treatment of shoulder pain in hemiplegic adults is fundamental to patient independence because the pain discourages patients from performing upper limb movements, which subsequently impairs functional recovery ${ }^{5}$. This study directly examined the effect of shoulder pain on upper limb function and daily independence following a stroke.

\footnotetext{
'Universidade Federal do Paraná, Departamento de Terapia Ocupacional, Curitiba PR, Brasil;

Universidade Federal do Paraná, Hospital de Clínicas, Divisão de Neurologia, Curitiba PR, Brasil;

${ }^{3}$ Hospital do Idoso Zilda Arns, Divisão de Terapia Ocupacional, Curitiba PR, Brasil.

Correspondence: Renato Nickel; Rua Lothário Meissner, 632/Bloco Didático II/Sala 1/4º Andar; 80210-170 Curitiba PR, Brasil; E-mail: rnickel@ufpr.br

Conflict of interest: There is no conflict of interest to declare.

Received 18 May 2016; Received in final form 10 October 2016; Accepted 31 October 2016.
} 
In particular, the ability to perform daily activities and performance issues were examined.

\section{METHODS}

This descriptive study followed stroke patients cared for at the Stroke Outpatient Clinic of the Hospital de Clínicas at the Federal University of Paraná. All patient data was prospectively collected during routine clinic visits between September 2012 and December 2013. This study followed Resolution 466/2012/CNS and was approved by the Research Ethics Committee at our institution (legal opinion number 107.805, CAAE 03585212.50000.0102). To be included in the study, the patient must have had only one previous stroke (hemorrhagic or ischemic) and be older than 18 years of age. Patients with other disabling diseases or previous shoulder pain (prior to stroke) were excluded.

All patients were evaluated using the Functional Independence Measure (FIM), the modified Ashworth Scale (MAS, measure of upper limb spasticity ${ }^{6}$ ), the Visual Numeric Scale for pain $(\mathrm{VNS})^{7}$, and the Scale for Upper Limb Function in Stroke (SULFS). A semi-structured, biopsychosocial model of the World Health Organization, International Classification of Functioning, Disability and Health ${ }^{8}$ based questionnaire was also administered to collect data on major activity limitations and restrictions. The VNS was determined by direct questioning and/or evaluation of passive movement of the impaired arm. The VNS is a 10-point scale with scores of $0=$ no pain, 1-3 = mild pain, 4-7 = moderate pain, and 8-10 = severe pain. The SULFS was also scored based on direct observation of upper limb movement and hand function (Table 1).

Patients were divided into those who had shoulder pain (shoulder pain group [SPG]) and those who did not have shoulder pain (no shoulder pain group [No-SPG]). Frequency, descriptive, and correlative data were evaluated within and between groups. A chi-squared or Fisher's exact test was used to compare categorical variables. The Mann-Whitney U-test and Student's t-test were used to compare differences in continuous variables. Spearman's correlation coefficients were used to examine correlations between MAS and SULFS data.

Table 1. Scoring definitions for the Scale for Upper Limb Function in Stroke (SULFS).

\begin{tabular}{|c|c|}
\hline Points & Criteria \\
\hline 1 & No upper limb movement. \\
\hline 2 & $\begin{array}{l}\text { Upper limb movement only with compensatory } \\
\text { patterns. }\end{array}$ \\
\hline 3 & $\begin{array}{l}\text { Able to position the upper limb without difficulty, but no } \\
\text { functional use of the hand. }\end{array}$ \\
\hline 4 & Uses the hand as an aid with compensation patterns. \\
\hline 5 & Normal usage of the hand. \\
\hline
\end{tabular}

Statistical analyses were performed using SPSS statistical software (ver. 20, SPSS, Inc., Chicago, IL) and statistical significance was defined as $\mathrm{p}<0.05$.

\section{RESULTS}

A total of 82 patients were considered for study inclusion, but only 58 patients $(70.7 \%)$ met all inclusion criteria. Twenty-two (37.9\%) of the included patients were female. Ischemic stroke had occurred in $56(96.6 \%)$ patients and the right side of the body was affected in 45 patients $(77.6 \%)$. Included patients had an average age of $49.2 \pm 10.8$ years and had study evaluations performed $3.52 \pm 2.26$ months after stroke.

The average FIM in all 58 patients was $108.12 \pm 18.98$. The main International Classification of Functioning, Disability and Health limitations and restrictions were "major life areas" (d8) in 15 (25.9\%) patients, "mobility" (d4) in 13 patients $(22.4 \%)$ patients, and "community, social, and civic life" (d9) in six patients (10.3\%). Ten patients (17.2\%) did not report problems with daily life activity performance or social participation. The median MAS score was 1 (range: $0-2$ ) for all 58 patients and none had neuropathic or thalamic pain.

A total of $19(32.8 \%)$ patients reported pain. Of these, 16 (27.6\%) reported shoulder pain, one (1.7\%) reported knee pain, one reported lumbar spine pain (1.7\%), and one (1.7\%) reported cervical region pain. The SULFS revealed that 28 patients $(48.3 \%)$ had normal use of the affected hand, four (6.9\%) had use of the affected hand as an aid (albeit with compensation patterns), two (3.4\%) had no difficulty positioning the affected upper limb (no functional use of the hand), 14 (24.1\%) had only upper limb movement with compensatory patterns, and 10 patients $(17.2 \%)$ had no upper limb movement. Table 2 summarizes the clinical characteristics of patients with and without shoulder pain.

Spearman correlation analysis revealed that the MAS and SULFS scores were significantly correlated (correlation coefficient $=-0.861, \mathrm{p}<0.01)$. This indicated that patients with a lower muscle tone had a higher limb function.

\section{DISCUSSION}

Shoulder pain occurred after stroke in $27.6 \%$ of our patients. Patients with shoulder pain had reduced upper limb function and lower daily functional independence when compared to patients without shoulder pain. The incidence of shoulder pain following stroke reported here is similar that reported by previous prospective studies ${ }^{1,5}$. Unfortunately, shoulder pain is not characterized by a specific definition and the quality of care of these hemiplegic patients widely varies by context and population ${ }^{3}$. It should be noted that our study population was younger than that of previous studies ${ }^{1,5,9,10,11}$.

The causative mechanism for shoulder pain after stroke is not fully understood, but is multifactorial. This is supported by 
Table 2. Characteristics of patients with and without shoulder pain.

\begin{tabular}{|c|c|c|c|}
\hline Data & SPG & NoSPG & $P$ \\
\hline Age, years & $49.2 \pm 13.2$ & $49.1 \pm 10.0$ & 0.989 \\
\hline $\begin{array}{l}\text { Time after stroke, } \\
\text { months }\end{array}$ & $3.44 \pm 1.70$ & $3.55 \pm 2.44$ & 0.870 \\
\hline n, patients & 19 & 39 & - \\
\hline Female, n (\%) & $6(37.5)$ & 16 (38.09) & 0.684 \\
\hline $\begin{array}{l}\text { Ischemic stroke, } \\
\mathrm{n}(\%)\end{array}$ & $16(100)$ & $40(95.23)$ & 0.812 \\
\hline $\begin{array}{l}\text { Right side affected, } \\
n(\%)\end{array}$ & $11(68.75)$ & 34 (80.95) & 0.405 \\
\hline Subluxation, n (\%) & $8(50)$ & $5(11.90)$ & 0.03 \\
\hline Rehabilitation, n (\%) & $16(100)$ & $19(45.23)$ & $<0.01$ \\
\hline FIM & $91.06 \pm 14.65$ & $114.62 \pm 2.27$ & $<0.01$ \\
\hline $\begin{array}{l}\text { MAS, median } \\
\text { (range) }\end{array}$ & $1+(1-2)$ & $0(0-2)$ & $<0.01$ \\
\hline $\begin{array}{l}\text { SULFS, median } \\
\text { (range) }\end{array}$ & $2(1-4)$ & $5(1-5)$ & $<0.01$ \\
\hline
\end{tabular}

Data are presented as mean \pm standard deviation where applicable. SPG: shoulder pain group; No-SPG: no shoulder pain group; FIM: functional independence measure; MAS: modified Ashworth scale; SULFS: scale for upper limb function in stroke; n: number.

the fact that shoulder pain occurs on and off through different recovery periods after stroke. During the flaccid recovery stage, excessive and intense muscular stretching can occur, resulting in soft tissue lesions and consequent pain. During the spastic recovery stage, spasticity patterns (adduction and internal rotation) may trigger pain ${ }^{12}$.In addition, subluxation and the need for transfer assistance, which may result in inappropriate pulley use, are important factors in shoulder pain after stroke ${ }^{2,3,4}$. Beside this, shoulder pain after stroke has been associated with a slower improvement in movement after stroke ${ }^{12}$.

The most important findings of the present study are the associations between shoulder pain and function of the upper limb and between shoulder pain and the level of functional independence. Previous studies have shown a relationship between shoulder pain and upper limb limitations, but, even though the FIM was used (as is in the current study), the impact of shoulder pain on daily life limitations and restrictions after stroke was not clear ${ }^{1,9,10,11}$. Furthermore, it is known that patients who need more assistance, especially during transfer, have a higher incidence of shoulder pain ${ }^{3}$. From this perspective, it is possible that shoulder pain discourages upper limb use and activity performance. It may also be assumed that the need for assistance, or a lower functional level, can result in the onset of pain.

Evidence from this study and prior studies indicates that pain generally begins within eight weeks of stroke ${ }^{5,8}$. The current study also demonstrated that pain was moderate to severe in intensity, which is in agreement with the literature, and that shoulder subluxation was more common in patients with shoulder pain. Subluxation is thought to be associated with motor function and muscle tone impairment and, in such cases, pain results from soft tissue injury ${ }^{3,10}$. Thus, subluxation may be a risk factor for developing shoulder pain ${ }^{5}$.

Interestingly, this study showed that all patients with shoulder pain were receiving rehabilitation care. However, most patients without shoulder pain were not receiving rehabilitation services. This finding may indicate that shoulder pain motivates care providers to refer a patient for treatment and maintenance rehabilitation services.

This study had several limitations. All patients were patients at the same hospital-based outpatient clinic, which is where all study examinations were performed. Additionally, our sample size was relatively small. A strength of our current study is that study evaluations were based on both patient information and physical examination. This is important because patients in previous studies denied pain when questioned, but complained of pain during physical examination. Therefore, asking hemiplegic patients about their pain may not be sufficient for identifying shoulder pain ${ }^{5}$.

In conclusion, the presence of shoulder pain in patients after stroke is likely related to the function level of an affected upper limb. This pain discourages limb movement and affects functional recovery. Although the current study indicated a possible correlation between shoulder pain and limb performance after stroke, the relationship between this condition and activity/participation is not yet clear.

\section{References}

1. Joy AK, Ozukum I, Nilachandra L Khelendro T, Nandabir Y, Kunjabasi W. Prevalence of hemiplegic shoulder pain in post-stroke patients: a hospital based study. IJPMR. 2012;23(1):15-9.

2. Zorowitz RD, Hughes MB, Idank D, Ikai T, Johnston MV. Shoulder pain and subluxation after stroke: correlation or coincidence? Am J Occup Ther. 1996;50(3):194-201. http://doi.org/10.5014/ajot.50.3.194

3. Coskun Benlidayi I, Basaran S. Hemiplegic shoulder pain: a common clinical consequence of stroke. Pract Neurol. 2014;14(2):88-91. http://doi.org/10.1136/practneurol-2013-000606

4. Gilmore PE, Spaulding SJ, Vandervoort AA. Hemiplegic shoulder pain: implications for occupational therapy treatment. Can J Occup Ther. 2004;71(1):36-46. http://doi.org/10.1177/000841740407100108
5. Dromerick AW, Edwards DF, Kumar A. Hemiplegic shoulder pain syndrome: frequency and characteristics during inpatient stroke rehabilitation. Arch Phys Med Rehabil. 2008;89(8):1589-93. http://doi.org/10.1016/j.apmr.2007.10.051

6. Bohannon RW, Smith MB. Interrater reliability of a modified Ashworth scale of muscle spasticity. Phys Ther. 1987;67(2):206-7.

7. Ciena AP, Gatto R, Pacini VC, Picanço VV, Magno IM, Loth EA. Influência da intensidade da dor sobre as respostas nas escalas unidimensionais de mensuração da dor em uma população de idosos e de adultos jovens. Semin Ciênc Biol Saúde. 2008;29(2):201-12. http://doi.org/10.5433/1679-0367.2008v29n2p201

8. Organização Mundial da Saúde. CIF: Classificação Internacional de Funcionalidade, Incapacidade e Saúde. São Paulo: EDUSP; 2003. 
9. Lindgren I, Ekstrand E, Lexell J, Westergren H, Brogårdh C. Somatonsensory impairments are common after stroke but have only a small impact on post-stroke shoulder pain.J Rehabil Med. 2014;46(4):307-13. http://doi.org/10.2340/16501977-1274

10. Chae J, Mascarenhas D, Yu DT, Kirsteins A, Elovic EP, Flanagan SR et al. Poststroke shoulder pain: its relationship to motor impairment, activity limitation, and quality of life. Arch Phys Med Rehabil. 2007;88(3):298-301. http://doi.org/10.1016/j.apmr.2006.12.007
11. Lindgren I, Brogardh C. Poststroke shoulder pain and its association with upper extremity sensorimotor function, daily hand activities, perceived participation, and life satisfaction. PM R. 2014;6(9):781-9. http://doi.org/10.1016/j.pmrj.2014.02.015

12. Vafadar AK, Côté JN, Archambault PS. Effectiveness of functional electrical stimulation in improving clinical outcomes in the upper arm following stroke: a systematic review and meta-analysis. Biomed Res Int. 2015;2015:729768. http://doi.org/10.1155/2015/729768 